\title{
THE FATE OF THE LARVAL ORGANS IN THE METAMORPHOSIS OF OSTREA EDULIS
}

\author{
By H. A. Cole, M.Sc. \\ Fisheries Experiment Station, Conway
}

(Text-figs. I-8)

\section{Introduction AND Review of Previous Work}

It has long been realized that the free-swimming larva of the European oyster (Ostrea edulis) must undergo considerable anatomical reorganization when it attaches itself as spat and takes on the fixed life of the adult oyster. The details of these changes have remained obscure. The fully developed "ansatzreifen" oyster larva has been admirably described and illustrated by Erdmann (1934). The smallest settled spat of which there is an adequate description is that figured by Yonge (I926). This specimen had a shell $\mathrm{I} \cdot 2 \mathrm{~mm}$. in length and must have been fixed for not less than 5 or 6 days, and possibly considerably longer; it had in most respects the structure of the adult oyster. It is clear that there is a considerable gap in our knowledge. A preliminary note by the writer (1937) gave information on a few points, particularly the rate of development of the gills and the changes in the adductor muscles. A further note (Cole, 1938) described a pair of sense organs of a new type found in the early fixed stages. In this, the first part of this study, the fate of the characteristic larval organs-the velum, foot, eyespots and adductor muscles-is described. The changes in gills, mantle, digestive system, etc., which take place during the first few days after attachment will be described in another publication.

Our knowledge of the metamorphosis of the larva of the American Atlantic oyster (O. virginica) is considerable, due chiefly to the efforts of Ryder (I882-84), Jackson (I888-90), and particularly Stafford (I9I3). In his monograph on The Canadian Oyster (O. virginica), Stafford gives a full account of the anatomy of both the fully developed larva and the earliest settled spat, and discusses the transition in detail. During recent years Prytherch (1934) has devoted further attention to this species. Although concerned mainly with the physiological requirements during attachment and metamorphosis, Prytherch gives a description and figure of the fully developed larva and discusses the fate of some of the larval organs, in particular the so-called pigment spots.

Roughley (1933) in his account of the life history of the Australian oyster (O. commercialis) gives a good description of the larva, but deals only briefly with the anatomical reorganization at fixation. The course of events in this 
species was in general so similar to that described by Stafford for $O$. virginica that he did not consider it necessary to give a detailed description. Hori (I926) gives some figures of the larva and spat of the common Japanese oyster (O. gigas) but does not consider the anatomical changes. In a later paper (1933) he describes also the development of the larva up to the setting stage in O. lurida, his figures being reproduced by Hopkins (I937). Although there are numerous other well-known species of oysters in no instance has the metamorphosis received any attention.

It has been customary (see Yonge, I926) to assume that the metamorphosis of $O$. edulis follows very closely that of $O$. virginica, but it will be seen from the subsequent pages that this is not so, although it is possible that a reinvestigation of certain points in the development of $O$. virginica may bring these two closely related species into line.

\section{Material AND METHODS}

The source of all material, both larvae and early spat, has been the oysterbreeding tanks of the Ministry of Agriculture and Fisheries at Conway. Since I9I8 experiments in breeding $O$. edulis have been carried out in large concrete tanks, a description of which was published by the writer in 1936 . Fully developed larvae were obtained by townet from the tanks and were fixed in Bouin's solution. No special precautions were taken to fix larvae in the expanded condition, since the collection of suitable material had to be carried out in odd moments during the summer when the breeding experiments were in progress. Larvae were simply dropped into tubes of Bouin's solution, and in practice the fixation was excellent and no trouble was experienced in determining the relations of the different organs in the contracted condition. For the study of the early spat stages, oyster shells which had been in the tanks a few days while settlement was in progress, and which were liberally sprinkled with spat, were immersed in Bouin's solution and later transferred to alcohol. In consequence of the decalcification of the surface layers of the shells, brought about by the acid in the fixative, it was later possible to brush off the spat without damage. Such shells yielded spat of all ages down to those which were in the act of settling, and, in fact, gave also some larvae which were merely wandering over the surface of the shell in search of a suitable place for attachment. More than a hundred such early spat were later embedded in paraffin and sectioned at a thickness of 8-10 $\mu$. A large number of eyed larvae were also sectioned for comparison. No attempt was made to orientate the larvae or spat, as it was expected that a sufficient number would be cut in all planes to present an adequate picture of their anatomy. This in practice proved to be the case. Sections were stained with Ehrlich's acid haematoxylin and eosin. A large number of larvae and early spat were also prepared as whole mounts, Ehrlich's acid haematoxylin or alum-carmine being used for staining. A certain number of spat were caught 
on glass slides immersed in the tanks, and these slides were removed at known intervals and placed in fixative. These spat of known age were subsequently prepared as whole mounts and gave useful information on the speed of metamorphosis. Spat of known age for sectioning were obtained by immersing shells for fixed periods and later detaching the spat set thereon. Some aspects of the metamorphosis could be studied in living material, e.g. the disappearance of the eyespots, the growth of the shell and gills, etc.

The illustrations have in all cases been prepared from camera lucida drawings.

\section{BRIEF DESCRIPTION OF THE LARVA OF OSTREA EDULIS}

Although the fully developed oyster larva has been so well described by Erdmann, it will be necessary to give here a brief description of its outstanding features. The larva is characterized first of all by the possession of a large and muscular ciliated velum, which when protruded from the shell serves for both locomotion and food collection. When the shell is closed the velum occupies the fore-part of its cavity. The mouth is situated at the base of the velum on its posterior surface, between the velum and the foot-a long strap-shaped organ which develops only during the last day or so before attachment. The interior of the foot is occupied by the byssus gland which provides the secretion with which attachment is effected. On each side of the body of the larva a large eyespot develops a few days before attachment and is easily seen on account of the transparency of the shell and mantle at this stage. There are two adductor muscles, anterior and posterior, symmetrically placed in relation to the hinge. The anus is posterior, slightly dorsal to the posterior adductor. The nervous system in the larva consists of cerebral and pleural ganglia in the velum, pedal ganglia in the base of the foot, and visceral ganglia near the posterior adductor. There is a pair of statocysts in the base of the foot, near the pedal ganglia. Gills are not well developed in the larva, but Erdmann figures a row of six extremely short knob-like processes along the left side. During the process of attachment the larva comes to lie on the left or more convex valve of the shell.

\section{The Velum}

The fate of the velum of the lamellibranch larva, and in particular of its contained apical sensory area, has been the subject of considerable speculation. The suggestion that in Ostrea the velum was cast off was first put forward by Davaine (I852). A few years previously Lovén (I848) had suggested that in the forms studied by him the labial palps of the adult were derived from the apical area of the velum. This view was, however, rejected by later workers, among them Ryder (I882), who studied the metamorphosis of $O$. virginica, and it was not until the publication in I90I of Meisenheimer's great work on the life history of Dreissensia polymorpha that the subject received the attention 
that it deserved. Meisenheimer described and illustrated the disintegration and absorption of the velum of Dreissensia, and showed clearly that the apical area was not lost but came to lie astride the oesophagus, and later fused with the upper lip of the mouth and did in fact form the basis of the labial palps.

Meisenheimer's work was apparently unknown in America for several years, as Sigerfoos (1908) and Stafford (1913), in discussing the metamorphosis of Ostrea virginica, make no reference to it. Sigerfoos, in his work on the development of shipworms (Teredinidae), refers incidentally to observations which he had made on $O$. virginica. He considered that the velum disappeared in its entirety very soon after attachment. He did not consider it possible that any part of the velum should give rise to the palps. Stafford (I9I3) gives a full account of the changes taking place at fixation in $O$. virginica. He states that after attachment the velum quickly atrophies, and in spat which had still in most respects the structure of the larva the velum was already shrunken and collapsed, the outline being rather vague. Immediately the spat began to grow, probably only a few hours after fixation, the velum was "so far gone as to be unrecognizable", and by the time the spat had increased its size by one-eighth "there remained only vestiges, chiefly of its muscles". Stafford discusses at length the possible loss of a part of the whole of the velum by "dehiscence", but came to the conclusion that no such "dehiscence" occurred. His material, however, was limited, consisting of sections of six spat only of the requisite size. Stafford, although unfamiliar with Meisenheimer's work, was acquainted with the views of Lovén regarding the origin of the palps. He was, however, of the opinion that the apical area of the velum played no part in the development of the palps. He found their origin in a thick-walled invagination dorsal to the oesophagus which later spread around and enveloped the mouth, giving rise to upper and lower palps by the growth of the outer and inner edges of the cavity. Concerning the interpretation of Stafford's sections further remarks will be made later in this paper.

Field (1922) in his study of Mytilus edulis came to the conclusion, from the examination of whole mounts only, that the labial palps of the adult were derived in the manner described by Meisenheimer. As far as I am aware no further attention has been paid to the subject during recent years.

A close study of my sections of very early spat makes it clear that in Ostrea edulis at least, the upper palps develop in a manner similar to that described by Meisenheimer for Dreissensia. Immediately after attachment the apical area of the velum becomes detached from the surrounding tissue and sinks into the interior of the velum, coming to lie dorsal to the oesophagus some distance from the surface of the body (Figs. I and 2). Here it is still associated with the cerebro-pleural ganglia of the larva. At the same time the velum collapses and is carried forward and upward by the rotation of the body. The mouth comes to lie just below the anterior adductor with the velar 


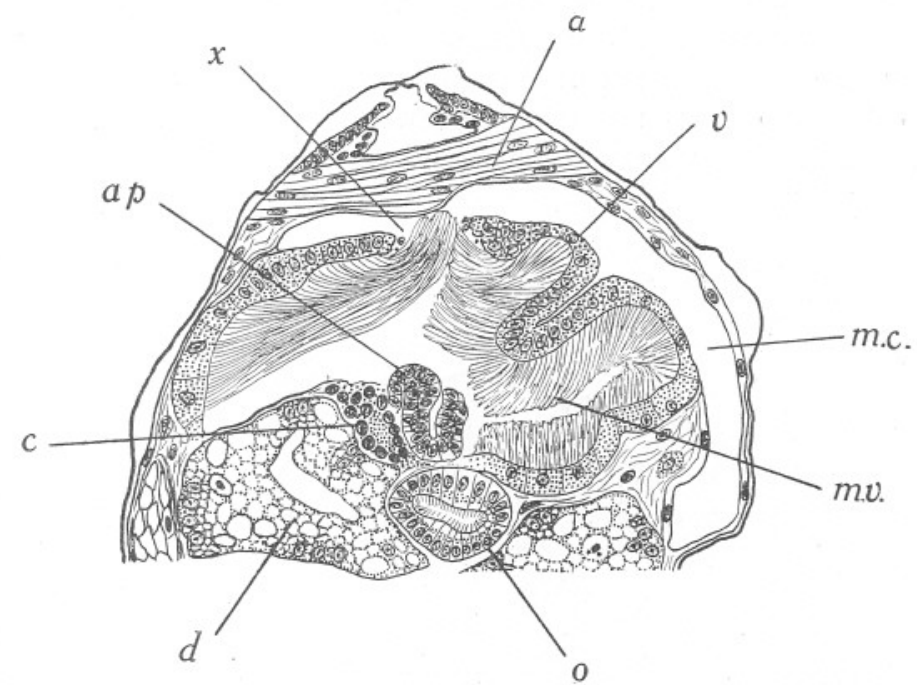

Fig. I. Horizontal section of anterior end of oyster spat a few hours after attachment, showing the apical area of the velum detached from the surrounding tissues and lying astride the oesophagus. $a$, anterior adductor muscle; $a p$, apical area of velum; $c$, cerebro-pedal ganglion; $d$, digestive diverticulum; m.c., mantle cavity; m.v., muscle fibres of velum; $v$, velum; $x$, former position of apical area of velum.

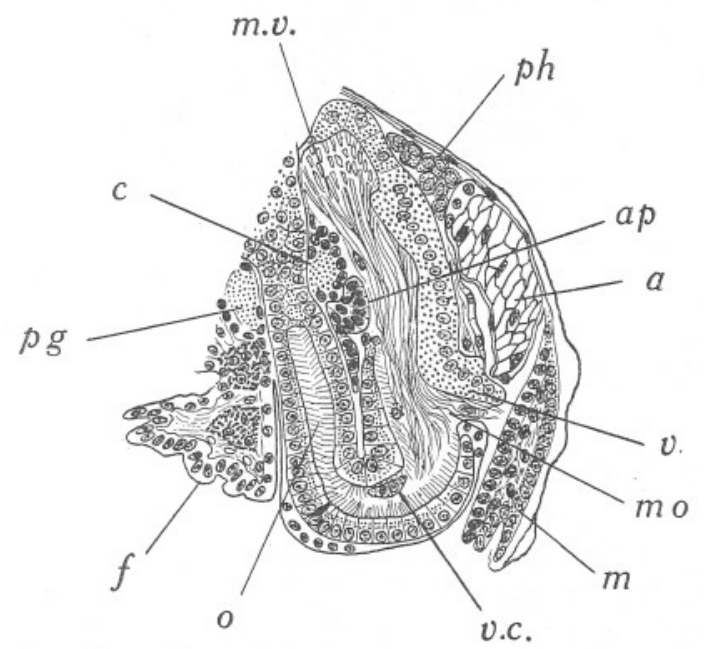

Fig. 2. Sagittal section of anterior end of oyster spat a few hours after attachment, showing the oesophagus bent round on itself, with the mouth directed inwards and blocked by velar muscles and detached cells. $a$, anterior adductor muscle; $a p$, apical area of velum; $c$, cerebro-pleural ganglion; $f$, foot; $m$, mantle; mo, mouth; $m . v$., muscle fibres of velum; $o$, oesophagus; $p h$, phagocytes; $v$, velum; v.c., detached velar cells. 
remnants occupying a position between them. As the velar remnants sink more deeply into the body, the mouth, which is closely bound up with the stalk of the velum, is dragged in also and the oesophagus is for a while bent round so that the mouth faces inwards instead of outwards (Fig. 2). Due to the sinking of the apical area of the velum and the general collapse and dis-

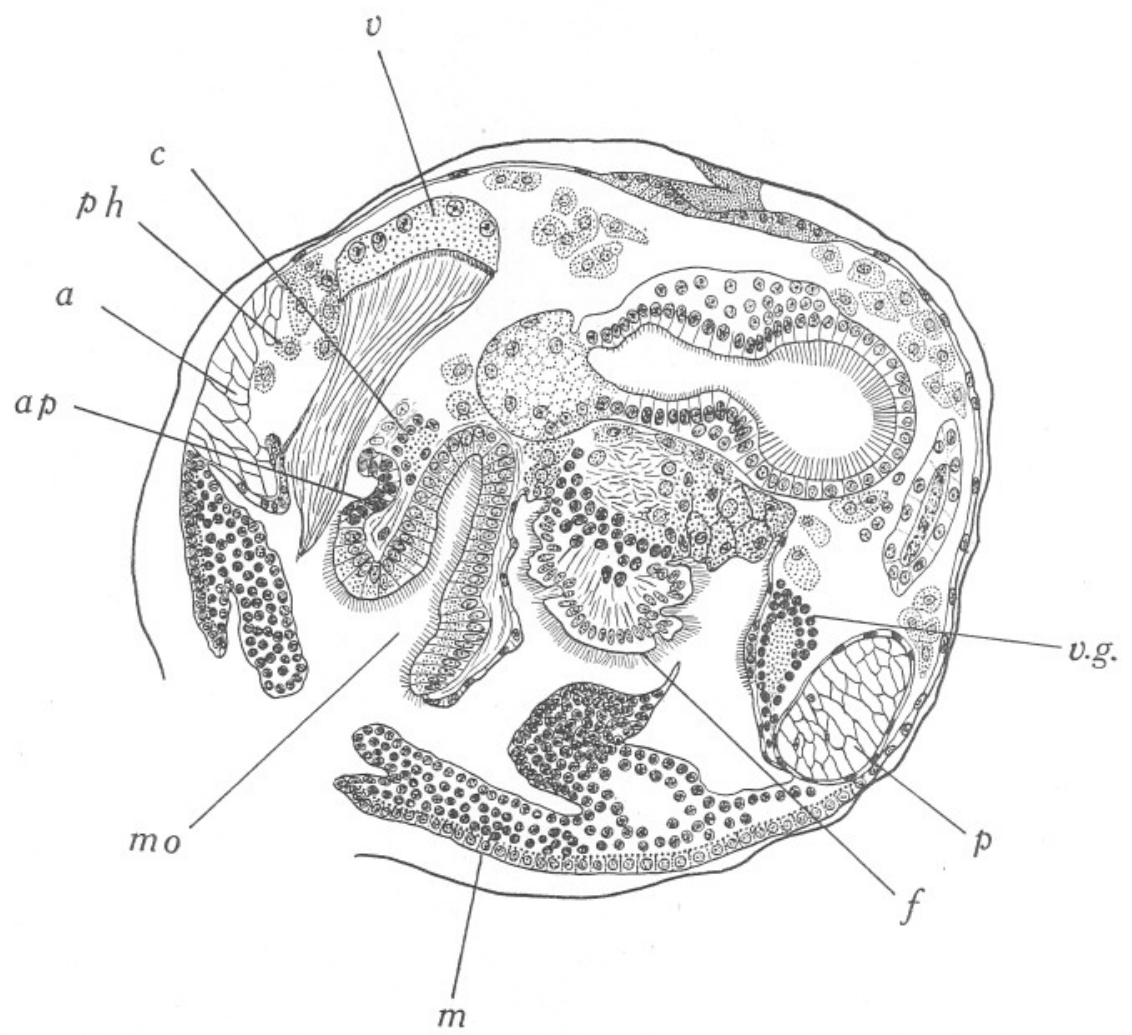

Fig. 3. Sagittal section of oyster spat about $24 \mathrm{hr}$. after attachment, showing the degenerating foot, the velar remnants practically enclosed within the body, and the apical area of the velum fusing with the upper lip of the mouth. $a$, anterior adductor muscle; $a p$, apical area of velum; $c$, cerebro-pleural ganglion; $f$, foot; $m$, mantle; $m o$, mouth; $p$, posterior adductor muscle; $p h$, phagocytes; $v$, velum; v.g., visceral ganglion.

integration of the latter organ, the muscle fibres which filled its cavity project from the body wall as a shaggy mass. While the mouth is bent inwards in the manner described above, it is practically blocked by these fibres and by detached velar cells, and, with the rapid dissolution of the velar tissues which is going on, it seems fairly certain that some of the remnants are swallowed. Such an occurrence would be by no means unusual in the metamorphosis of marine larvae. This bent position of the oesophagus does not persist for long, certainly not more than $24 \mathrm{hr}$., for the tension is relieved by the dis- 
integration of the velar tissues. The apical plate moves along the oesophagus until it occupies a position directly above the mouth. Underlying it at this stage traces of the cerebro-pleural ganglia may still be seen. The apical plate now fuses with the epidermis of the upper lip (Fig. 3). At this stage, which is reached about $24 \mathrm{hr}$. after fixation, the velar remnants consist of a little of the typical epithelium of the thickened edge and some of the muscle fibres of the interior. These latter still project from the body wall between the mouth and the degenerating anterior adductor. Subsequently the much thickened upper lip spreads out laterally, and gives rise to short rounded lobes which project, one on each side, at the upper corners of the mouth (Fig. 5). These are the

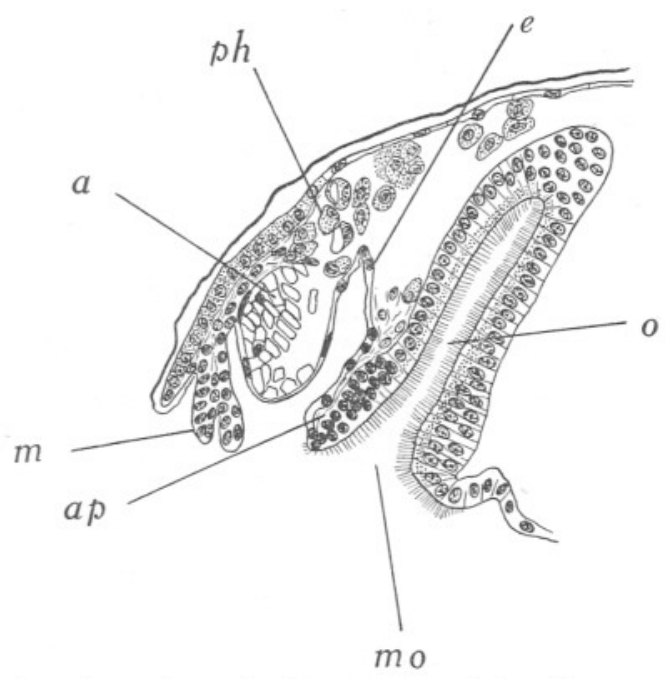

Fig. 4. Sagittal section of anterior end of oyster spat $48 \mathrm{hr}$. after attachment, showing the apical area of the velum completely incorporated with the upper lip of the mouth, and the epithelium of the body wall closed over the area formerly occupied by the velum. $a$, anterior adductor muscle; $a p$, apical area of velum; $e$, epithelium covering area formerly occupied by the velum; $m$, mantle; mo, mouth; $o$, oesophagus; $p h$, phagocytes.

rudiments of the upper, or outer, palps of the adult oyster. This stage is reached $48 \mathrm{hr}$. after attachment. During this period the velum also disappears completely, and a thin epithelium grows across between the palps and the remnant of the anterior adductor (Fig. 4). There can be no doubt that a great deal of the velar tissue breaks up and is lost or eaten. From a close study of Stafford's figures, and the text which accompanies them, I am of the opinion that it is not improbable that a re-examination of the development of the palps in Ostrea virginica will show that it follows a course very similar to that described above.

Later spat show the upper palps slightly more elongated and pointed (Fig. 6), the upper lip being drawn forward to form a hood over the mouth. Spat 3 or 4 days old show, however, no trace of the inner palps, unless the thickened 


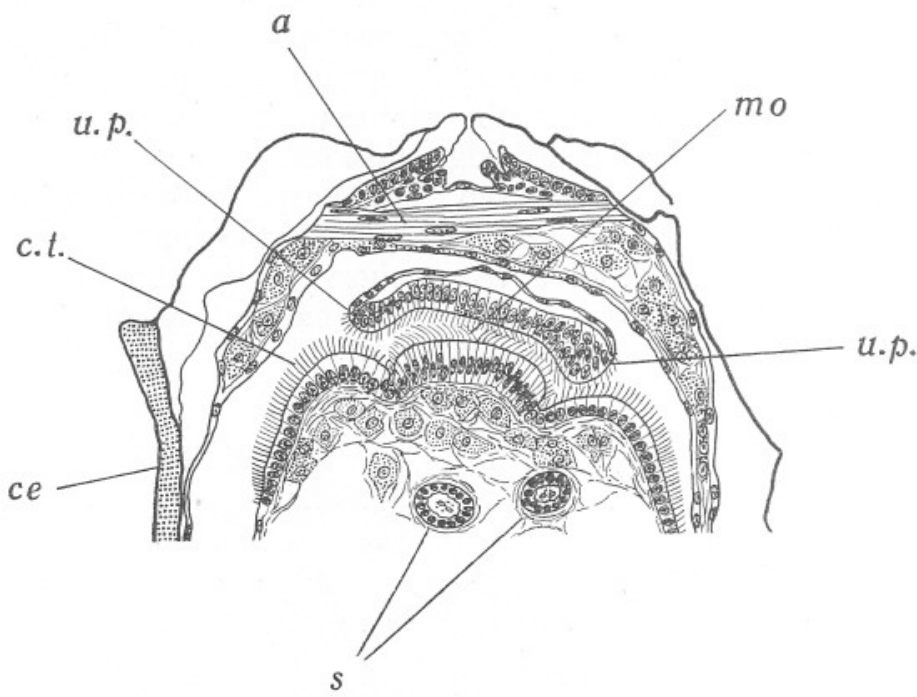

Fig. 5. Horizontal section of anterior end of oyster spat about $48 \mathrm{hr}$. after attachment passing just below the mouth, showing the lateral spreading of the upper palp rudiments, and the position of the statocysts. $a$, anterior adductor muscle; $c e$, cementing material; c.t., ciliated tract at base of gills; $m o$, mouth; $s$, statocysts; u.p., upper palps.

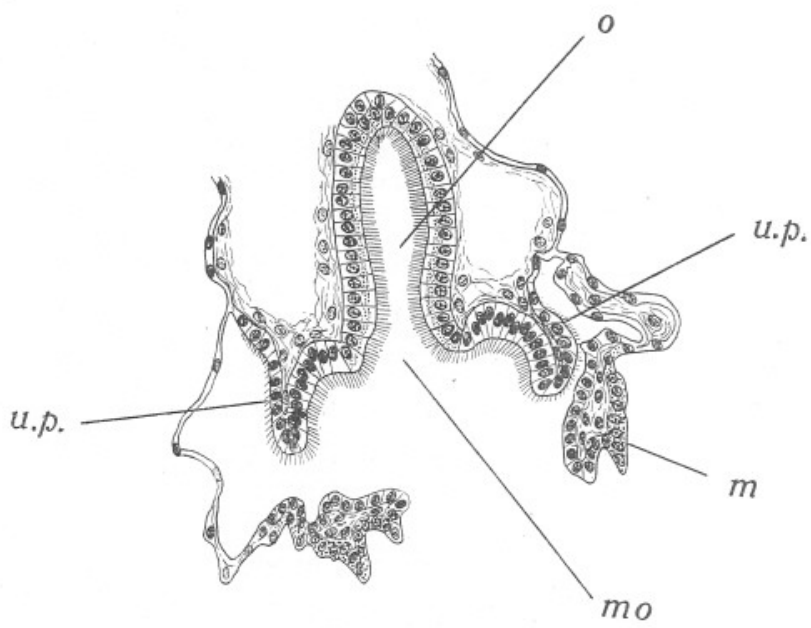

Fig. 6. Frontal section of oyster spat 3-4 days after attachment, showing the mouth and upper palps. $m$, mantle; mo, mouth; o, oesophagus; u.p., upper palps. 
nature of the rim round the mouth and in particular of the lower lip is an indication of their derivation from this source. In Dreissensia Meisenheimer states that the lower palps develop some time after metamorphosis as outgrowths from the upper palps. My material unfortunately does not extend beyond spat of 3-4 days old, none of which have the lower palps developed. These spat had shells about $0.6 \mathrm{~mm}$. in length, while the smallest spat described by Yonge had a shell $\mathrm{I} \cdot 2 \mathrm{~mm}$. across. This individual had, however, relatively enormous palps, both upper and lower palps being well developed. It is probable that it had been settled not less than 5 or 6 days, but even so it is clear that the growth of the palps must be very rapid after the changes associated with metamorphosis have been completed.

\section{The Foot}

The foot develops very rapidly in the larva during the last $24 \mathrm{hr}$. or so before settlement. In the fully developed larva the foot is a long strap-shaped organ which projects from the body in the region between the mouth and the posterior adductor muscle. It is capable of being protruded between the valves for a distance at least equal to the diameter of the shell. Besides serving for locomotion on the substratum immediately prior to attachment, the foot is a highly sensory and glandular organ. The greater part of the base of the foot is occupied by the byssus gland which opens along the sole by a ciliated groove. Although the actual process of attachment in Ostrea edulis has not been described, there is no longer any doubt (see Erdmann, I934) that this gland produces the cement with which the left shell of the larva is attached permanently to the substratum. Spat fixed to shells and subsequently detached by decalcification show a definite thick pad of homogeneous cement underlying the left valve (see Fig. 5). After fixation a little cement remains in the byssus gland and on staining takes up eosin with great avidity. The fate of this residual cement is easy to follow as in slightly more advanced spat phagocytes may be seen crammed with an eosinophilous substance which has every indication of being residual byssus material. The foot gradually shrinks in size following fixation and is carried forward by the rotation of the mouth until it occupies an almost mid-ventral position, projecting from the body wall behind the mouth as an irregular crumpled mass clothed with rather shaggy cilia (Fig. 3). The regular columnar epithelium which clothes the foot remains distinct for some time. Internally the pedal ganglia may be distinguished for about $24 \mathrm{hr}$. after fixation, although their outlines are rather vague. At this stage the glandular cells of the byssus cavity are also still quite distinct. In spat which have been attached $48 \mathrm{hr}$. the foot projects only slightly from the body and its free border is rather vague, suggesting the loss of some of the tissues making up the distal part. Internally, the tissues of the byssus cavity may still be seen, but the pedal ganglia are no longer distinguishable. The whole region is much invaded by phagocytes, some of which contain recognizable elements of the byssus gland. The last traces of the foot 
are absorbed and the epithelium assumes a smooth outline before the spat is $72 \mathrm{hr}$. old. The absorption of the foot in $O$. virginica is apparently not complete until much later, as Stafford states that traces may be seen in spat up to a size of I mm. Otherwise the details of the process appear to be very similar.

Of the sensory structures of the larval foot only the statocysts persist in the adult. In the larva they are closely applied to the sides of the pedal ganglia, although innervated from the visceral ganglia (Erdmann, I934), and open on the base of the foot by a small pore. Following fixation and absorption of the foot they sink more deeply into the body until they come to lie below the root of the first gill filaments, ventral and slightly posterior to the mouth (Fig. 5). Their connexion with the exterior is lost. Such statocysts have already been described by Carazzi (1902) in the adult $O$. edulis, and were found also in O. chilensis by Dahmen (I923). I have received also a private communication from Prytherch which indicates their persistence in $O$. virginica. It seems probable that they are of frequent occurrence in oysters, although it is difficult to see what their function can be. They are stated not to occur in the adult O. cucullata (Awati \& Rai, I93I). It is possible that they may serve as organs for the detection of movement in the surrounding medium, but the special pallial sense organs described by the writer (1938) would seem to be better equipped for this purpose, inasmuch as they are situated on the mantle and are separated from the external medium by a thin epidermis only, while the statocysts on the other hand are rather deeply set and must be correspondingly insensitive to small disturbances.

\section{The Adductor Muscles}

Huxley (I883) was the first to suggest that the single adductor of the early oyster larva did not correspond to the single adductor of the adult. The posterior adductor of the late larva was discovered by Jackson (I888) working with $O$. virginica. Since that time it has been recognized that the single adductor muscle of the early larva corresponds to the anterior adductor of dimyarian molluscs, while the adductor of the adult oyster corresponds to the posterior adductor of these forms. It has further been recognized that the late larva of all species of oysters possesses two adductors more or less symmetrically placed with regard to the hinge. In the eyed larva of $O$. edulis at the time of settlement the two adductor muscles are approximately equal in size. Following fixation the anterior adductor begins to degenerate and at the same time is crowded to the edge of the shell (Fig. 3). The posterior adductor enlarges and moves ventrally and anteriorly towards the centre of the shell. In spat which are between 24 and $48 \mathrm{hr}$. old the sizes of the posterior and anterior adductors are in the ratio of $3: 2$. Forty-eight hours after settlement a fringe (dissoconch) has usually been added to the larval shell or prodissoconch. Thereafter the degeneration of the anterior adductor proceeds rapidly. Spat which have been fixed 3 days usually show a few fibres only at the extreme edge of the shell, while at 4 days all traces of the anterior shell 
muscle have disappeared. The posterior adductor has increased in size and moved ventrally until it lies just outside the prodissoconch attached to the dissoconch or definite shell of the adult. Such 4 days' old spat may be $6 \mathrm{~mm}$. in diameter. At this stage sections of the adductor muscle show no differentiation into "quick" and "catch" components.

\section{The Eyes, with Remarks on their Function during Attachment}

The eyes develop in the larva only during the last few days before settlement. They are a pair of spherical densely pigmented organs, situated in the body wall just dorsal to the attachment of the gill rudiments. In the living larva, when the velum is retracted, each eyespot can be seen underlying the valve of the shell at about its centre. The structure, function, and fate subsequent to metamorphosis of these organs have been the subject of considerable difference of opinion (see Prytherch, I934). In O. edulis the eyes are described in detail and figured by Erdmann (I934), each eyespot consisting of an almost spherical cup of pigmented epithelium filled with a gelatinous matrix and having its aperture closed by a lens-like body. It gives the writer great pleasure to confirm Erdmann's description, as considerable doubt has been thrown upon his interpretation of their structure. The degree of pigmentation and the situation of the pigment in the epithelium of the cup appear to vary somewhat in different individual larvae. In some instances the nuclei of the epithelium are so densely pigmented as to show little structure, while the cytoplasm

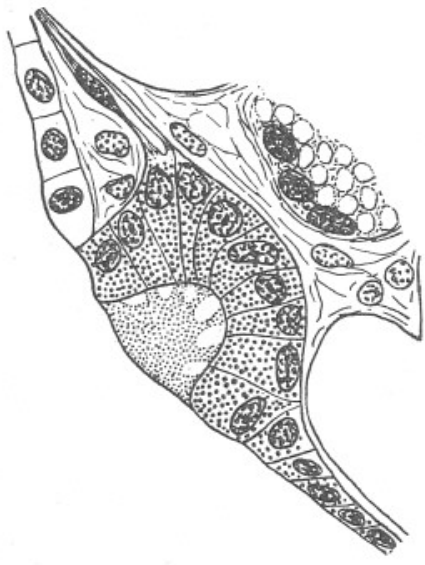

Fig. 7. Section through the eyespot of oyster spat just settled. above the nuclei may be practically free from pigment. In others the pigment is dense in the cytoplasm while the nuclei are more lightly pigmented.

In a recent paper (I934) the structure of the eyespots in the larva of $O$. virginica is discussed in detail by Prytherch. He describes in this species pigment spots which are "found on each side of the body as very conspicuous larval organs". According to this author they have not the structure of eyes and have been incorrectly described as such. In support of his contention he states that in the course of experiments over a period of 8 years he has found no evidence that oyster larvae are sensitive to light intensity or colour. It must be admitted in this connexion that no such phototropic responses have been demonstrated in the larva of $O$. edulis, but this may largely be explained by the fact that the possibility of such responses existing has not yet been explored. There can, however, be no doubt whatever about the eye-like structure of the "pigment spots" in this species (see Fig. 7). Hopkins (1937) has studied experimentally the setting of larva of $O$. lurida under natural 
conditions, and concludes that "light is not an orienting factor in the setting behaviour of larvae of this species". Although he made no detailed study of the pigment spots he concludes that they are not light sensitive organs, and is inclined to support Prytherch's view that they have an entirely different function. Nelson (1925), on the other hand, is of the opinion that the eyed larva of $O$. virginica exhibits a negative phototaxis, which is not apparent in younger larvae without eyespots. Regarding the eyespot and its function Nelson sțates: "This spot, although unable to form an image like a true eye, is sensitive to light.... In the presence of light these 'eyed' larvae of the oyster are stimulated and continue moving until they get into a shaded place, where they become quiescent." In this way he accounts for the preference exhibited by larvae for shady situations for attachment. It is clear, however, that the freedom of shady overhung situations from silt and encrusting growths is also an important factor in determining the density of settlement. Larvae of all species of oysters attach themselves only to clean surfaces, whether they are shaded or not. Roughley (I933) working with O. commercialis noted a tendency for the larvae to set in small depressions on the shells offered, as for example in the indentations between the teeth along the inner margins of the shells. A similar phenomenon has also been noted by Hopkins (I935). Roughley correlates this tendency with the increased protection against abrasion afforded by such situations. Hopkins (I935) has shown that the angle of inclination of the surface to the horizontal has an important effect on the intensity of setting in O. lurida. The more nearly the surface approaches the horizontal so does the intensity of setting on it increase. The present writer's experience with $O$. edulis in tanks has been similar, e.g. if two similar slates are put into the water, one at an angle of $45^{\circ}$ and the other horizontal, then the intensity of setting on the under side of the horizontal slate will be considerably greater than on the same side of that set at an angle. Further, on the under side of the half-round limed tiles in use at Conway the intensity of setting is always greater along the ridge of the tile where the surface is horizontal, than along the sides where the surface is at an angle. The nature of the surface presented, i.e. whether it is rough or smooth, seems also to be of importance, and the writer has noticed that among some test slates placed horizontally in the Conway tanks, one which had been ground smooth caught far less spat than others the surfaces of which had not been touched. Hopkins (I935) further produces experimental evidence in support of his contention that the greater intensity of setting of $O$. lurida on the underside of horizontal surfaces is not due to negative phototaxis. He compared the setting on horizontal glass plates placed in the sea for $24 \mathrm{hr}$., some of which were coated on the upper surface with black paint, while others were plain. The results showed a slightly greater number of larvae setting on the underside of the plain glass in the unshaded situation. He considers that the greater intensity of setting on the underside of horizontal surfaces which is generally experienced to be due to the fact that larvae swim with the velum and foot uppermost 
and thus the foot most frequently comes into contact with horizontal surfaces. In a recent paper (I937) the same author gives further details of his experiments but the conclusions are the same. There is, however, a great deal of evidence for the view that larval oysters exercise some selection in the choice of the site to which they eventually become attached. They do not attach themselves to the first surface with which they come into contact as Hopkins implies. Before attachment larvae of $O$. edulis, and indeed apparently of most species of oysters, pass through an exploratory phase, during which they crawl over the surface of the substratum, with the foot protruded in front and apparently acting as an important tactile organ. Further, the writer is of the opinion that, in O. edulis at least, attachment may be postponed for a while if a suitable surface is not presented. Such an ability to delay metamorphosis

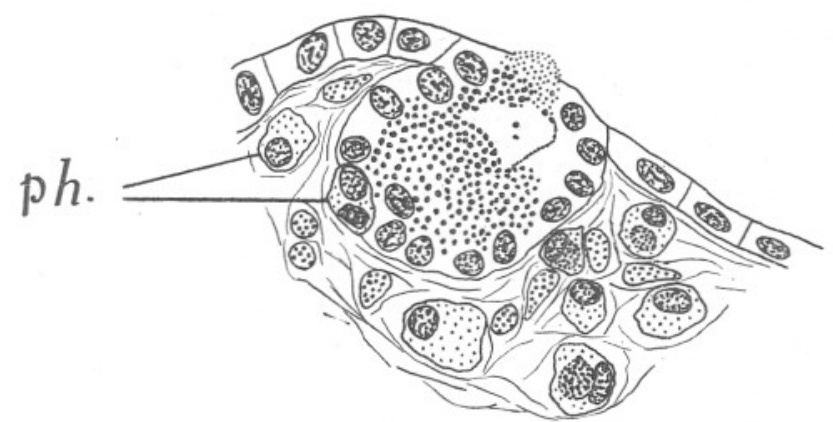

Fig. 8. Section through degenerating eyespot of oyster spat, a few hours after attachment. ph, phagocytes.

until a suitable surface is available is possessed by the larvae of several species of polychaete worms, and in the opinion of Wilson (I937) has an important influence on the survival rate after metamorphosis. It is clear that the whole question of the factors influencing oyster larvae at the time of attachment needs to be examined more closely.

Prytherch describes in detail the dispersal of the pigmented cells in $O$. virginica, and their migration to the blood stream. In this species the break-up of the pigment spots is very rapid as the following statement shows: "When setting is in progress, the pigmented cells in each spot gradually enlarge, separate and one or two break away and are carried forward by the blood stream into the mantle. After attachment the pigment spot breaks apart more rapidly, and all the cells become distributed in a short time into the circulatory system, as the process of transformation of the larva is in full swing. Each pigment spot consists of approximately 300 cells, which after separation resemble in many respects the leucocytes of the spat and adult oyster." It is unfortunate that Prytherch should not have figured sections of larvae and early spat which would support his findings, but in a recent private communication to the writer he re-affirms his view that "these 
structures are not light sensitive organs, but function chiefly as leucocytegenerating tissue from which cells migrate to the blood stream during metamorphosis".

Concerning the fate of the eyespots Stafford offers no information, nor in fact does any writer other than Prytherch. In O. edulis the eyespots disappear as such after the first $24 \mathrm{hr}$. of attached life. Soon after attachment the eyes become less conspicuous due apparently to some loss of the black pigment. They tend also to sink below the epithelium of the body which later closes over them. There seems to be no reason to doubt that they are broken down in situ and the pigmented cells ingested by phagocytes. The details of this breakdown process naturally vary in different spat. The pigment usually disappears quickly from the nuclei. The outline of the epithelial cup becomes irregular and invading phagocytes may be seen (Fig. 8). With the breakdown of the cells, the pigment is liberated into the centre of the cup and lies in irregular clumps, the granules of which are considerably larger than those in the functional eye. Phagocytes are very numerous in the connective tissue underlying the eye. The final stages of the disintegration is represented by a group of phagocytes many of which contain cells and nuclei with much black pigment, which have every appearance of having formed part of the larval eyespot. That such phagocytes while still containing the remains of the pigmented epithelium of the eye may wander to other parts of the body is not unlikely, and this may create the illusion that the pigmented eye-cells are actually functioning as leucocytes. No separation and dispersal of the pigmented cells, such as Prytherch describes, has however been observed, the disintegration and absorption of the eyespots going on in situ.

\section{SUMMARY}

This is the first part of a study of the metamorphosis of the larva of the European flat oyster (Ostrea edulis) and deals with the fate of the larval velum, foot, adductor muscles and eyespots.

The apical area of the larval velum forms the basis of the upper labial palps of the spat.

The bulk of the velar tissue is broken up and cast off or eaten; the total dissolution of the velum being complete within $48 \mathrm{hr}$. of attachment.

The larval foot after effecting attachment rapidly shrinks in size and disappears within $72 \mathrm{hr}$. of attachment. Partial loss of its tissues probably occurs.

The statocysts persist in the spat.

Following fixation the anterior adductor muscle rapidly degenerates.

The so-called pigment spots of the larval oyster have the structure of eyes. During metamorphosis they degenerate rapidly in situ.

A discussion of the function of the eyespots during attachment reveals the need for further critical experiments. 


\section{REFERENCES}

Awati, P. R. \& RaI, S. H., I93I. Ostrea cucullata (The Bombay oyster). Indian Zool. Memoir, No. 3. Lucknow.

CARAZZI, D., I902. Contributo all' istologia e alla fisiologia dei lamellibranchi. Intern. Monatschr. Anat. Phys., Bd. xx.

Cole, H. A., I936. Experiments in the breeding of oysters (Ostrea edulis) in tanks, with special reference to the food of the larva and spat. Min. Agric. Fish., Fish. Invest., Ser. II, Vol. xv, No. 4, pp. I-25.

_- 1937. Metamorphosis of the larva of Ostrea edulis. Nature, Vol. 139, No. 35I4, p. 413 .

— 1938. New pallial sense organs in early fixed stages of Ostrea edulis. Nature, Vol. I4I, No. 3560, p. I6I.

Dahmen, P., I923. Anatomie von Ostrea chilensis (Phillipi). Fena. Zeitschr. f. Naturwiss., Bd. LIX, pp. 575-625.

Davarne, C., I852. Recherches sur la génération des huitres. C.R. Soc. Biol., Paris, Vol. IV, p. 297.

ERDMANN, W., I934. Über die Entwicklung und die Anatomie der "ansatzreifen" Larve von Ostrea edulis, mit Bemerkungen über die Lebensgeschichte der Auster. Wiss. Meeresunters. Abt. Helgoland, N.F., Bd. xix, pp. I-25.

FIeld, I. A., I922. The biology and economic value of the sea mussel Mytilus edulis. Bull. Bur. Fish., Washington, Vol. xxxvIII, pp. I-259.

Hopkins, A. E., I935. Attachment of larvae of the Olympia oyster, Ostrea lurida, to plane surfaces. Ecology, Vol. xvI, pp. 82-7.

- 1937. Experimental observations on spawning, larval development, and setting in the Olympia oyster, Ostrea lurida. Bull. Bur. Fish., Washington, Vol. XLvirI, pp. 439-503.

HoRI, J., I926. Notes on the full grown larva and the Japanese common oyster, Ostrea gigas Thunberg. Fourn. Imp. Fish. Inst., Vol. xxII, No. I, pp. I-7.

- I 933 . On the development of the Olympia oyster, Ostrea lurida Carpenter, transplanted from United States to Japan. Bull. Fap. Soc. Sci. Fish., Vol. I, pp. $269-76$.

HuxLey, T. H., I883. Oysters and oyster question. Eng. Illust. Mag., Oct. and Nov., pp. $47-55$, II $2-2$ I.

JACKSON, R. T., I888. Catching fixed forms etc. Science, Vol. xI, No. 275, p. 230.

- I889. The development of the oyster with remarks on allied genera. Proc. Boston Soc. Nat. Hist., Vol. xxiII, pp. 53I-56.

- I890. The phylogeny of the Pelecypoda. Mem. Boston Soc. Nat. Hist., Vol. Iv, pp. $277-400$.

Lovén, S., I848. Archiv f. Naturg., Bd. xv.

Meisenheimer, J., I 901 . Entwicklungsgeschichte von Dreissensia polymorpha Pall. Zeitschr.f. wiss. Zoolog., Bd. LXIX, pp. I-I37.

Nelson, T. C., 1925. Rep. of the New Fersey Agric. Exp. Station, pp. $28 \mathrm{I}-8$.

PRYTHERCH, H. F., I934. The role of copper in the setting, metamorphosis, and distribution of the American oyster, Ostrea virginica. Ecol. Monogr., Vol. 4, pp. 47-107.

Roughley, T. C., I933. The life history of the Australian oyster (Ostrea commercialis). Proc. Linn. Soc. New South Wales, Vol. LviII, pp. 279-333.

RYDER, J. A., I882. Notes on the breeding, food and green colour of the oyster. Bull. U. S. Fish. Comm. I88I, Vol. I, pp. 403-19.

- I883. On the mode of fixation of the fry of the oyster. Bull. U. S. Fish. Comm., Vol. III, pp. 383-87. 
RYder, J. A., I884. The metamorphosis and post-larval stages of development of the oyster. Rep. U.S. Fish. Comm. I882, Vol. x, pp. 779-79r.

Sigerfoos, C. P., I908. Natural history, organisation and late development of the Teredinidae, or shipworms. Bull. Bur. Fish., Washington, Vol. xxvII, pp. I9I$23 I$.

Stafford, J., I9I3. The Canadian Oyster. Ottawa.

WILSON, D. P., I937. The influence of the substratum on the metamorphosis of Notomastus larvae. Fourn. Mar. Biol. Assoc., Vol. xxir, pp. 227-43.

YONGE, C. M., I926. The structure and physiology of the organs of feeding and digestion in Ostrea edulis. Fourn. Mar. Biol. Assoc., Vol. xIv, pp. 295-386. 